\title{
GO CAP LAK: RITUAL DAN IDENTITAS BARU ETNIS TIONGHOA DI BAGANSIAPIAPI
}

\author{
Oleh : Zuli Laili Isnaini
}

\begin{abstract}
His paper aims to describe the ritual Fuel Barge Chinese society into a new cultural identity for people of Chinese descent in Bagansiapiapi. Fuel barges or known by the name of Go Cap Lak Bagansiapiapi only found in the district and conducted annually by the people of Chinese descent.

Go Cap Lak ceremony is an annual ritual held by the Chinese community in Bagansiapiapi the fifth month (Go) Imlek on the sixteenth (Cap Lak) as an expression of gratitude and thanks to the God of the Sea Gods Kie Ong Ya have provided prosperity and health.

Go Cap Lak ceremony fuel barge is present only in Bagansiapiapi and serve as an icon of cultural identity or to attract tourists. In the development of this program is to increase the diversity of economic and social life in the city Bagansiapiapi. Ritual Go Cap Lak or fuel barge into a new identity for a long time Bagansiapiapi and shifting identity as a city of the world's number two producer of fish in the middle of the 20 th century into a tourist city.
\end{abstract}

\section{Keyword : Go Cap Lak, Bakar Tongkang, Bagansiapiapi}

\section{Pendahuluan}

Bagansiapiapi adalah salah satu ibukota kabupaten di Provinsi Riau, berada di muara Sungai Rokan tepatnya berada di kabupaten Rokan Hilir dengan jarak $328 \mathrm{~km}$ dari utara kota Pekanbaru. Posisinya yang strategis di pantai Timur Sumatera menjadikan Bagansiapiapi pernah menjadi pelabuhan besar di dunia. Berdasarkan catatan sejarah, Bagansiapiapi pernah menjadi kota nelayan dengan penghasil ikan terbesar ke-2 di dunia setelah Norwegia. Alfan, Zainal (http:// kab-rokanhilir.bpn.go.id/Propinsi/ $\underline{\text { Riau/Kabupaten-Rokan-Hilir) Arus }}$ masuknya masyarakat keturunan Tionghoa pada awalnya berasal dari para imigran dari negeri Tirai Bambu (sekarang RCC) yang sengaja di bawa oleh Belanda untuk dipekerjakan sebagai pekerja tambang di Sumatera. Kepulauan Bangka yang berada di pantai timur pulau Sumatera (sekarang masuk dalam wilayah provinsi BangkaBelitung) yang terkenal akan tambang timah pada waktu itu membutuhkan banyak pekerja, dan orang-orang Cina dikirim untuk dijadikan buruh tambang (Poerwanto: 2005). Skiner (1981) menuliskan bahwa datangnya orangorang Cina ke Bangka berasal dari provinsi Kwangtung, Tiongkok untuk bekerja pada pertambangan timah sejak abad ke-17. Harian Kompas 
(14 April 2005) juga memaparkan adanya gelombang besar pekerja asal Cina di tahun 1710 untuk menjadi pegawai tambang secara kontrak pada pemerintah Belanda. Pemerintah Belanda akan memberikan keuntungan yang besar bagi orang Cina yang mau bekerja sebagai pegawai tambang.

Awal abad ke-20 tepatnya di tahun 1907-1940 dengan sponsor perusahaan Holland - China Handless Companie para imigran semakin banyak berdatangan, terlebih adanya konflik perebutan kekuasaan di Cina pada zaman tersebut. Seperti yang ditulis du Kompas edisi 14 April 2005 oleh WP Goeneveldt mengungkapkan bahwa pembahasan tentang Pulau Bangka pernah ditulis dalam kitab klasik China, Hsing-ch'a Shenglan, yang ditulis tahun 1436. Kitab itu menceritakan wilayah Bangka Belitung yang memiliki tradisi unik dan pemandangan indah dengan sungai-sungai dan tanah datar. Dalam penuturan beberapa literatur kuno, Bangka telah dikenal pelaut-pelaut China dan mereka pernah singgah di pulau Bangka serta memberinya nama Pu-lei sejak abad ke-3 Masehi.

Selain bekerja di Bangka sebagai buruh tambang, merekajuga melakukan asimilasi melalui pernikahan dengan penduduk lokal yaitu Melayu sehingga lahirlah keturunan Tionghoa di pulau Sumatera. Diantara mereka banyak yang merantau ke daerah bernama Bagansiapiapiuntukmencarikehidupan selain untuk menjadi buruh tambang, yaitu sebagai nelayan (Purcell:1964).

Dalam sejarah lain dikatakan bahwa masuknya warga Tionghoa ke Bagansiapiapi karena banyaknya ikan dan udang di muara sungai Rokan yang tepat berada di kota tersebut. Vleming (1926:234) mengemukakan bahwa mereka merupakan kawanan bajak laut yang pada tahun 1875 beralih menjadi nelayan dan membuka pemukiman yang kemudian bernama Bagansiapiapi. Tulisan Butchler (1996:93) mendiskripsikan bahwa kekayaan ikan dan udang disebabkan oleh adanya sari pati yang dibawa oleh arus sungai dari daun dan pepohonan di hulu sungai Rokan dan mangrove yang menumpuk di muara sehingga memberikan nutrisi yang penting bagi kehidupan ikan. Oleh karena itu Bagansiapiapi kaya akan ikan dan industri perikanan menjadi faktor ekonomi nomor satu kala itu. Catatan Setyowati (2009) membuktikan bahwa antara tahun 1898 dan 1904 ekspor ikan kering meningkat dari 12,7 juta menjadi 25,9 juta $\mathrm{kg}$, sedangkan udang kering yang awalnya 0,1 juta naik hingga 0,2 juta $\mathrm{kg}$, sementara terasi mampu melonjak dari ekspor terendah 0,1 juta pada tahun 1898 ke 2,7 juta kg di tahun 1904 (ANRI MVO le Reel 16 Memorie van Overgave van van de Oferafdeling Bagansiapiapi, 1 November 1936.).

Masyarakat etnis Tionghoa memberikan andil paling besar dalam peningkatan industri perikanan karena mereka merupakan faktor produksi dalam kegiatan ekonomi di bidang perikanan. Hal ini selaras dengan apa yang dikemukakan oleh Shozo (1995:128) bahwa awal dibukanya Bagansiapiapi sebagai kota industri ikan, sampai tahun 1928 hampir seluruh penduduknya adalah etnis Tionghoa dan perikanan merupakan 
sumber kehidupan ekonomi di sana ( Economics Role of Southeast Asia Chinese on The Eve of World War III, Singapore: Selected book, Pte. Ltd. 1995).

Sekarang

kemasyhuran

Bagansiapiapi sudah meredup, kota industri ikan hanya tinggal sejarah yang terdapat pada kurikulum siswa Sekolah Dasar tahun 1994, selain menjadi pengetahuan umum mengenai geografi dan sosial ekonomi pada lingkungan masyarakat dan Pemerintah Daerah Rokan Hilir. Harian Kompas edisi 31 Oktober 2005 bertajuk Julukan Kota Ikan Itu, Kini Hanya Tinggal Nama..., menyiratkan matinya industri perikanan di Bagansiapiapi, bahkan kota yang awalnya dijuluki sebagai Kota Bercahaya atau "Vielle Lumiere" (Bagansiapiapi pernah menjadi kota yang bergelimang cahaya di malam hari diakibatkan dari pesatnya perekonomian perikanan dimana tahun 1934 listrik sudah menerangi kota tersebut di bawah Electrichtieit Mastchappij Balik Papan, juga Pengelolaan Air yang dapat mengubah air Sungai Rokan sebagai air minum dan air pemadam kebakaran. Selanjutnya di tahun 1936, baik penerangan listrik maupun pemadam kebakaran sudah menggunakan energy listrik. Dengan adanya aliran listrik, mekanisme pemadaman kebakaran menggunakan sirene yang diletakkan di atap kantor pembangkit listrik setinggi 5 meter yang suara sirene tersebut terdengar sejauh $30 \mathrm{~km}$ dan di malam hari, listrik sudah menerangi jalan dengan adanya lampu jalanan) sekarang seakan redup dan gelap-gulita karena sudah tidak ditemui pelabuhan ekspor ikan lagi.
Namun redupnya industri ikan tidak memupus kehidupan nelayan dan perikanan di Bagansiapiapi, khususnya bagi warga keturunan Tionghoa karena sekarang ini muncul sebuah ritual Bakar Tongkang atau Go Cap Lak yang disinyalir menjadi sebuah identitas tersendiri bagi warga keturunan Tionghoa Bagansiapiapi.

\section{Permasalahan}

1. Mengapa Bakar Tongkang atau Go Cap Lak dipilih oleh warga keturunan Tionghoa Bagansiapiapi sebagai ritual tahunan?

2. Apakah ritual tersebut hanya ada di Bagansiapiapi?

3. Bagaimana masyarakat keturunan Tionghoa memaknai ritual tersebut?

\section{Pembahasan}

Identitas merupakan sebuah kata yang sulit dimaknai dan tidak semua orang memiliki kesamaan dalam mengartikannya, sehingga belum ada kata baku dalam menterjemahkan arti dari identitas. Piliang (1999) berpendapat ibarat jalan yang berliku, itulah identitas. Seperti yang dilansir oleh Stuart Hall (1996:160) bahwa identitas merupakan sesuatu yang tidak sempurna, suatu proses yang selalu dibangun dari dalam yang mengacu pada konotasi sosial, politik, budaya, dan sebagainya. Abdillah (2002:2628) mengemukakan, suatu waktu dapat juga identitas berarti kekhawatiran, ketakutan, dan ke-akuan bila terjadi pada kondisi defensif. Pada kasuskasus dewasa ini yang mengglobal atau menasional muncul sebuah jargon identitas bangsa, sedangkan dalam 
disiplin ilmu psikologi muncul sebagai suatu pertanyaan.

Jean Baudrillard dalam Piliang (2002) menyangsikan adanya suatu identitas yang asli dan melekat ada atau orisinal dikarenakan semua hal telah mengalami dekonstruksi yang selanjutnya dalam kemajemukan yang berkembang akan berakibat subjek tersebut kehilangan identitas aslinya. Dalam hal ini identitas berlaku sebagai lokasi personal (1999:159). Pendapat lain diutarakan oleh Rutherford yang menganalogikan bahwa identitas merupakan sebuah tempat bernama rumah untuk tempat kembali dan dimulainya sesuatu. Dari sisi psikologi, identitas menunjuk pada kesadaran dan kesinambungan secara personal meskipun terjadi perubahan di sekelilingnya. Secara psikologis, makna identitas dapat ditelusuri melalui teori identifikasi. Pandangan ini awalnya dicetuskan oleh Sigmund Freud mengenai psikoanalisa yang dilanjutkan oleh tokoh-tokoh lainnya seperti Herbert Mead, Erik Ericson, Talcot Parson, dan Jurgen Habermas (2002:29).

Disamping itu Bloom (1990:25) mengatakan bahwa teori identitas tidak hanya mengenai struktur dan perkembangan psikologi yang diakibatkan oleh pengaruh-pengaruh sosial dan lingkungan secara politisi, namun secara metodologis penyelidikan secara individual sangat memungkinkan individu-individu tersebut akan bereaksi untuk menjaga, mempertahankan, dan memperbaiki serta memperkaya identitasnya.

Ritual Bakar Tongkang (Go Cap Lak) merupakan suatu ritual budaya yang sudah turun-temurun berada di Bagansiapiapi. Sejak tahun 1928 upacara Bakar Tongkang sudah dijalankan oleh orang-orang Cina yang tinggal di Bagansiapiapi sebagai ungkapan rasa syukur atas kekayaan ikan yang melimpah di tempat tersebut. Karena selama tahun-tahun tersebut panen ikan merupakan hasil yang memberikannilai ekonomipaling tinggi dibandingkan dengan hasil produksi pertanian (Shozo, 1995). Jantung perekonomian dimotori oleh perikanan dan pelaku ekonomi tersebut adalah orang-orang Cina yang membuka kota Bagansiapiapi, karena hampir semua penduduknya waktu itu adalah orang Cina maupun keturunannya. Hari Poerwanto(2005:81-82)yangmengutip tulisan Skinner menjelaskan bahwa sangat sulit untuk mengidentifikasi seorang Cina di Indonesia dikarenakan ketidakmampuan orang Cina di Indonesia untuk menulis dan berbahasa Cina. Selain itu telah terjadi perkawinan campuran antara orang Cina dengan warga asli daerah rantau pada generasi sebelumnya. Ketidaktahuan mengenai adat-istiadat dan budaya asli Cina dan pemujaan terhadap nenek moyang juga menyebabkan keturunan Cina tersebut kehilangan identitas ke-Cinaannya.

Penulis menggunakan panggilan orang Cina atau keturunan warga Tionghoa dengan berasumsi bahwa keduanya memiliki nilai yang sama. Untuk di Riau sendiri pemanggilan orang Cina maupun Tionghoa tidak memiliki arti yang berbeda, bahwa penggunaan Tionghoa maupun Cina, keduanya digunakan untuk memanggil etnis dengan ciri-ciri mata sipit, berkulit lebih berwarna dibandingkan kulit 
orang Melayu, dsb tanpa prejudice yang buruk. Di kota Bagansiapiapi sendiri sulit juga untuk mengidentifikasi mana yang merupakan orang Cina Totok atau yang keturunan karena mereka menggunakan dua bahasa, yaitu bahasa Melayu dan Bahasa Khek atau dialek Cina lainnya. Mereka hidup membaur dengan masyarakat Melayu, Jawa, Batak, Minang, dan Bugis dan melakukan kegiatan sosial dan ekonomi bersamaan sehingga mereka juga dapat menggunakan bahasa Indonesia.

Di Bagansiapiapi tidak dapat diketahui lagi apakah mereka merupakan keturunan Tionghoa atau Cina toktok karena jumlah mereka sangat banyak dan berbahasa Khek, disamping mereka juga sudah tidak mengerti lagi keluarga atau leluhur mereka yang tinggal di Cina. Meskipun masihbanyakwargaCinaBagansiapiapi yang memiliki keluarga di Malaysia atau di Singapura, namun mereka tidak pernah pulang ke negeri Cina. Dalam beribadah dan melakukan ritual budaya dan keagamaan, warga Cina atau keturunannya di Bagansiapiapi sekarang ini hanya mengikuti apa yang dilakukan oleh leluhur mereka. Mereka tidak mengetahui lagi apakah ritual itu sama atau tidak seperti yang dilakukan orang Cina yang tinggal di RRC.

Tujuan dari upacara Go Cap Lak adalah untuk memperingati ulang tahun Dewa Laut Kie Ong Ya dan pengucapan rasa syukur dan terima kasih atas kemakmuran hidup dan keselamatan yang diberikan kepada masyarakat Bagansiapiapi (Setyowati, 2009:1). Hal tersebut dilakukan sebagai pengingat terhadap pertolongan Dewa Kie Ong Ya yang telah menyelamatkan nenek moyang mereka ketika pergi dari Cina dengan menggunakan perahu kayu sederhana hingga sampai di Bagansiapiapi dengan selamat serta berada di tempat yang memiliki kekayaan ikan, sehingga sebagai perantau patut bersyukur telah mendapat kesempatan hidup yang lebih baik (http.//.www.wikipedia.org/ wiki/ritual_bakar_tongkang).

Upacara ini dilakukan pada penanggalan Imlek kelima (Go) dan tanggal ke-16 (Cap Lak), oleh karena itu istilah Bakar Tongkang biasa disebut Go Cap Lak. Pada awalnya, upacara Go Cap Lak yang biasanya dilakukan di sebuah kelenteng di Bagansiapiapi tidak semeriah sekarang, namun kemudian Go Cap Lak menjadi acara tahunan yang sangat meriah yang tidak hanya dihadiri oleh masyarakat Cina Bagansiapiapi saja, melainkan dari berbagai kota baik dari dalam maupun dari luar negeri (http// www.riautourismeboard.com/bakar/ tongkang, 8/6/2009).

Upacara Bakar Tongkang ini merupakan ritual yang hanya satusatunya ada di Bagansiapiapi. Bedasarkan teori Bloom (1990:25) di atas, Go Cap Lak lahir dan hadir di tengah-tengah masyarakat Tionghoa sebagai wujud kekayaan budaya yang terbentuk akibat keinginan bertahan hidup atau sebagai symbol survive yang dimiliki oleh para perantau dari Cina. Bertahan hidup di tempat asing tanpa ada yang dikenal tentu merupakan hal yang sulit, dan ketika perantau tersebut menemukan sebuah tempat dengan kekayaan alam yang melimpah berupa ikan, telah mengubah kehidupan yang awalnya dianggap sulit menjadi 


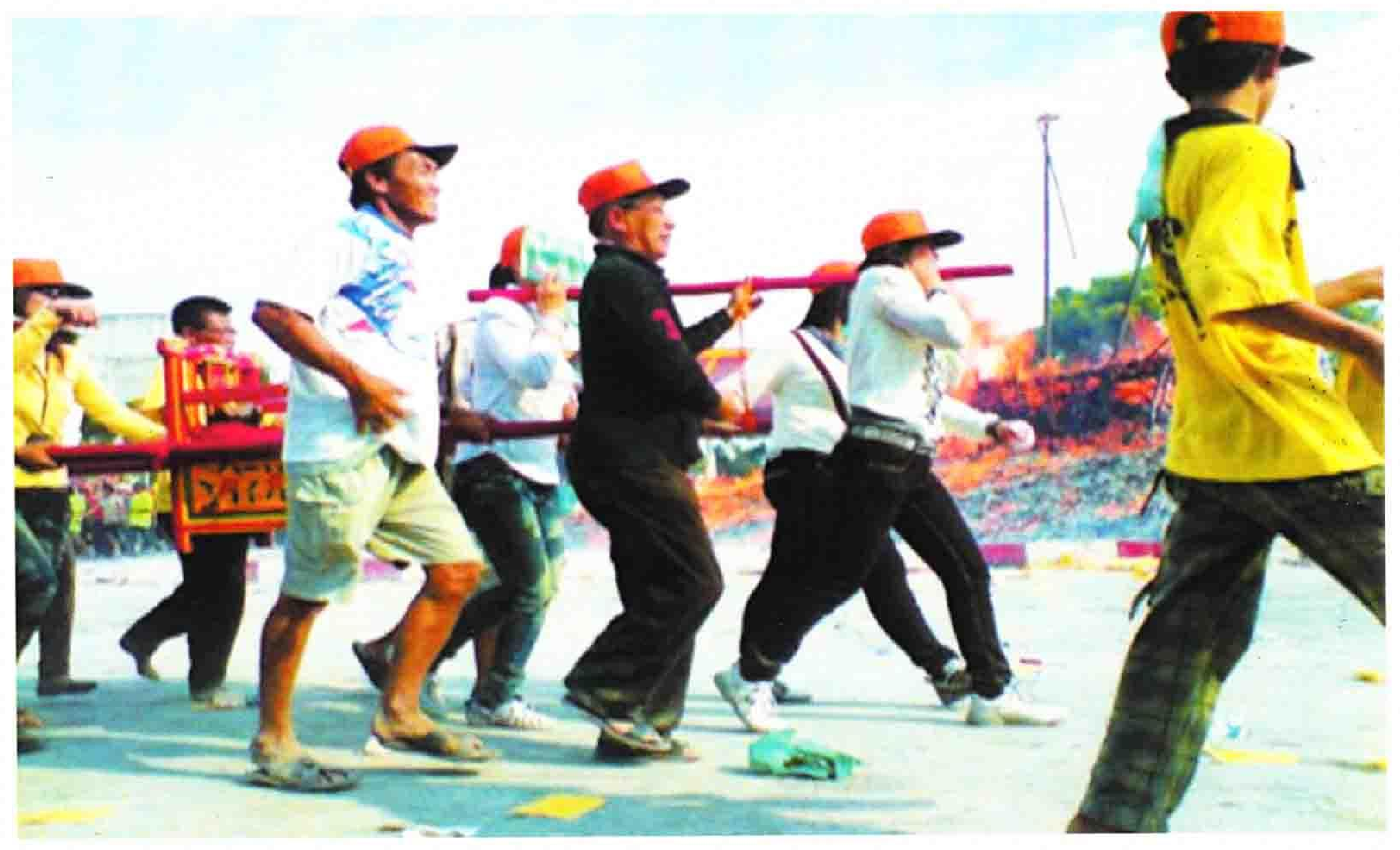

mudah. Oleh karena itu ritual Go Cap Lak menjadi sebuah awal dari identitas religius dan budaya orang Cina di Bagansiapiapi. Secara psikologis, alasan mendapatkan kehidupan yang baik menjadikan perantau Cina yang sukses, mensyukuri nikmat dan berdasarkan keyakinannya, maka mereka berterima kasih terhadap Dewa Ki Ong Ya.

Gambar diatas menunjukkan Warga Tionghoa yang berpartisiasi membawa peralatan music tradisional sebagai iringan tarian yang menyertai acara pembakaran tongkang. Gambar Ritual Bakar Tongkang 2011 (Sumber: www.bagansiapiapi.net-photo, diapload 28 Juni 2011)

Identitas-pun selanjutnya akan mengalami dekonstruksi Baudrillard melalui Piliang, 2002) dan selalu berubah (199:152) terlihat bahwa pada awalnya acara Bakar Tongkang (Go Cap Lak) yang dilakukan di salah satu kelenteng di kota Bagansiapiapi dan sekarang miniature tongkang dibakar pinggir pantai tentunya dengan berbagai pertimbangan, sejak otonomi daerah (sesudah tahun 1998) menjadi sangat mewah dan meriah. Miniatur tongkang atau perahu layar khas Bagansiapiapi, Riau ini dibuat dengan harga milyaran rupiah. Replika tongkang yang berbahan dasar kayu pilihan ini dibuat sangat besar dan mewah dengan hiasan khas Cina seperti lukisan naga, bendera-bendera yang berwarna-warni. Saat pembakaran tongkang juga disertai dengan ribuan bahkan jutaan replika uang Cina yang sebelumnya di arak dari alun-alun kota Bagansiapi-api menuju pinggir pantai. Dalam perayaan bakar tongkang, juga diramaikan oleh acara peragaan magic, tari-tarian, pawai, dan atraksi menyakiti diri sendiri oleh para warga Tionghoa/orang Cina yang ikut dalam ritual tersebut. 


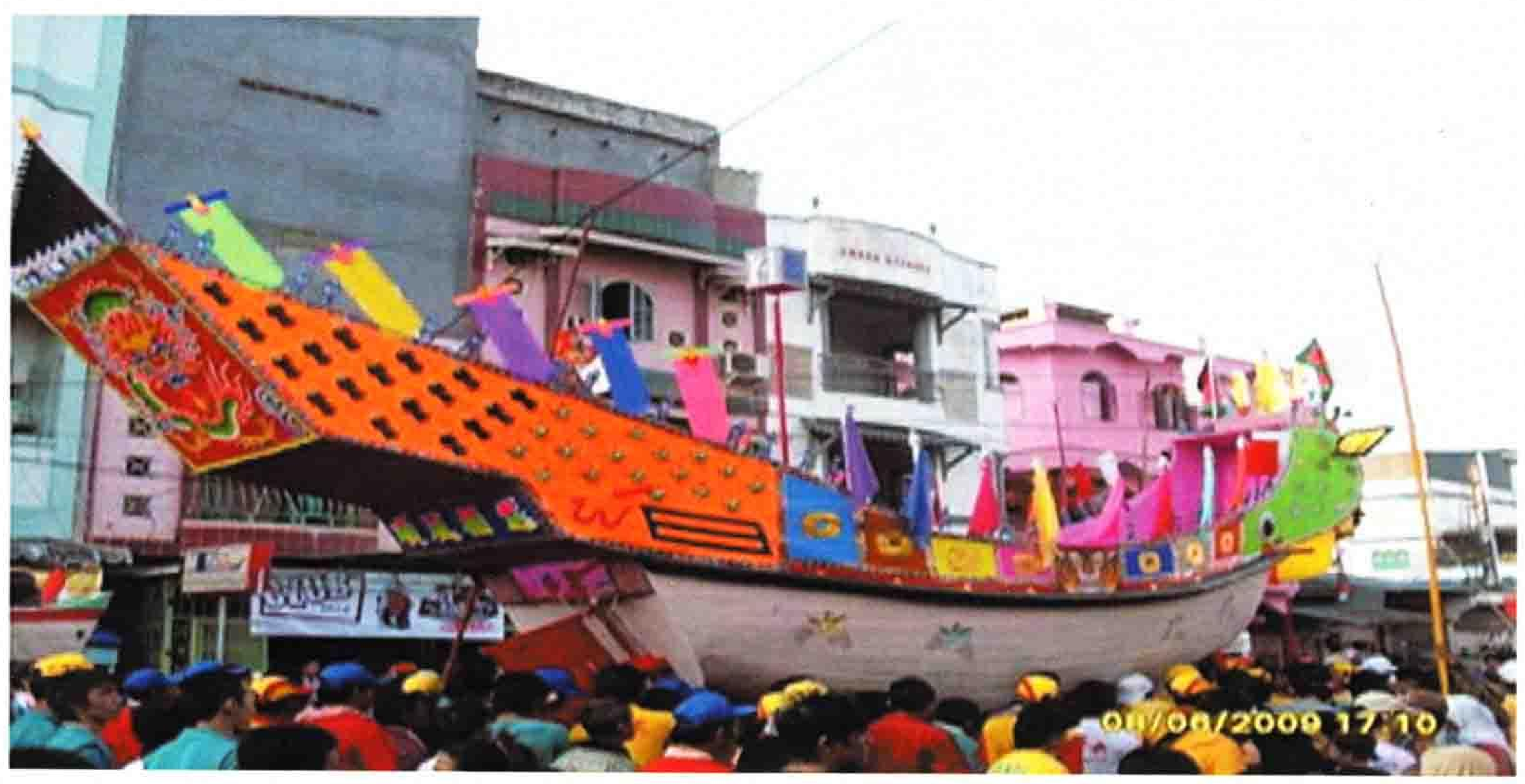

Replika Tongkang yang sedang di arak di kota Bagansiapiapi yang terjadi pada tahun 2009. (Sumber: Riautourismboard dari http//wwiw. riautourismboard-bakar-tongkang. html)

Upacara Bakar Tongkang tidak hanya diikuti dan disaksikan oleh warga Tionghoa saja, namun sekarang sudah menjadi acara wisata tahunan yang merupakan acara wajib bagi kota Bagansiapiapi. Baik bagi para warga keturunan Tionghoa maupun orangorang Cina yang melakukan ritual bakar

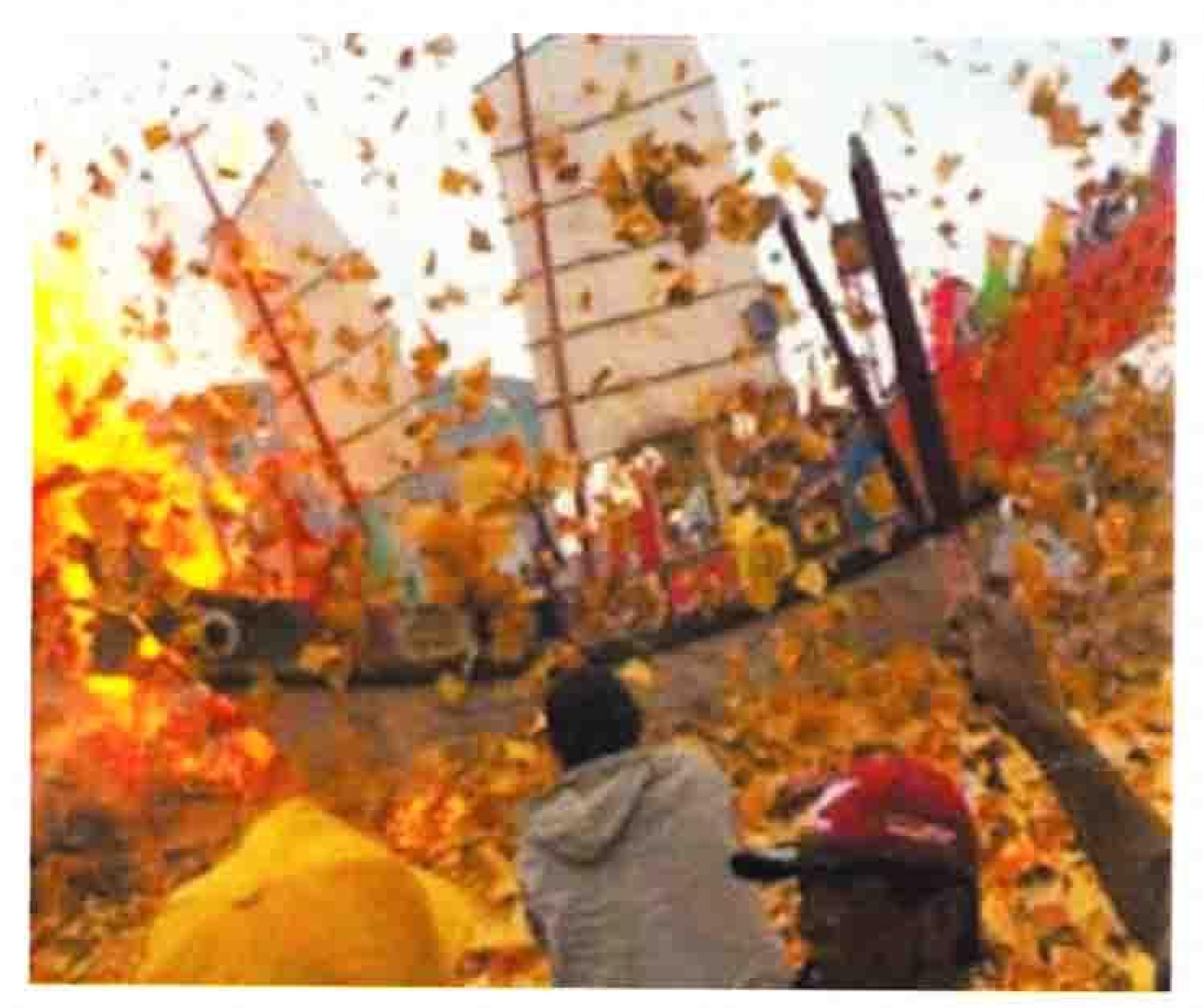

tongkang serta masyarakat umum yang menyaksikan termasuk wisatawan yang menyaksikan acara tersebut, diakhir ritual hal yang dinanti-nanti adalah menunggu ke arah mana replika tongkang yang telah terbakar akan jatuh (http//wwiw.riautourismboard-bakartongkang.html ). Bila jatuhnya replika tersebut ke arah laut atau air diyakini sumber rezeki akan didapatkan dari laut, begitupun sebaliknya.

Kedua gambar di bawah adalah replika tongkang ketika sedang di bakar. Sebelah kiri replika uang Cina dihamburkan ke atas tongkang yang

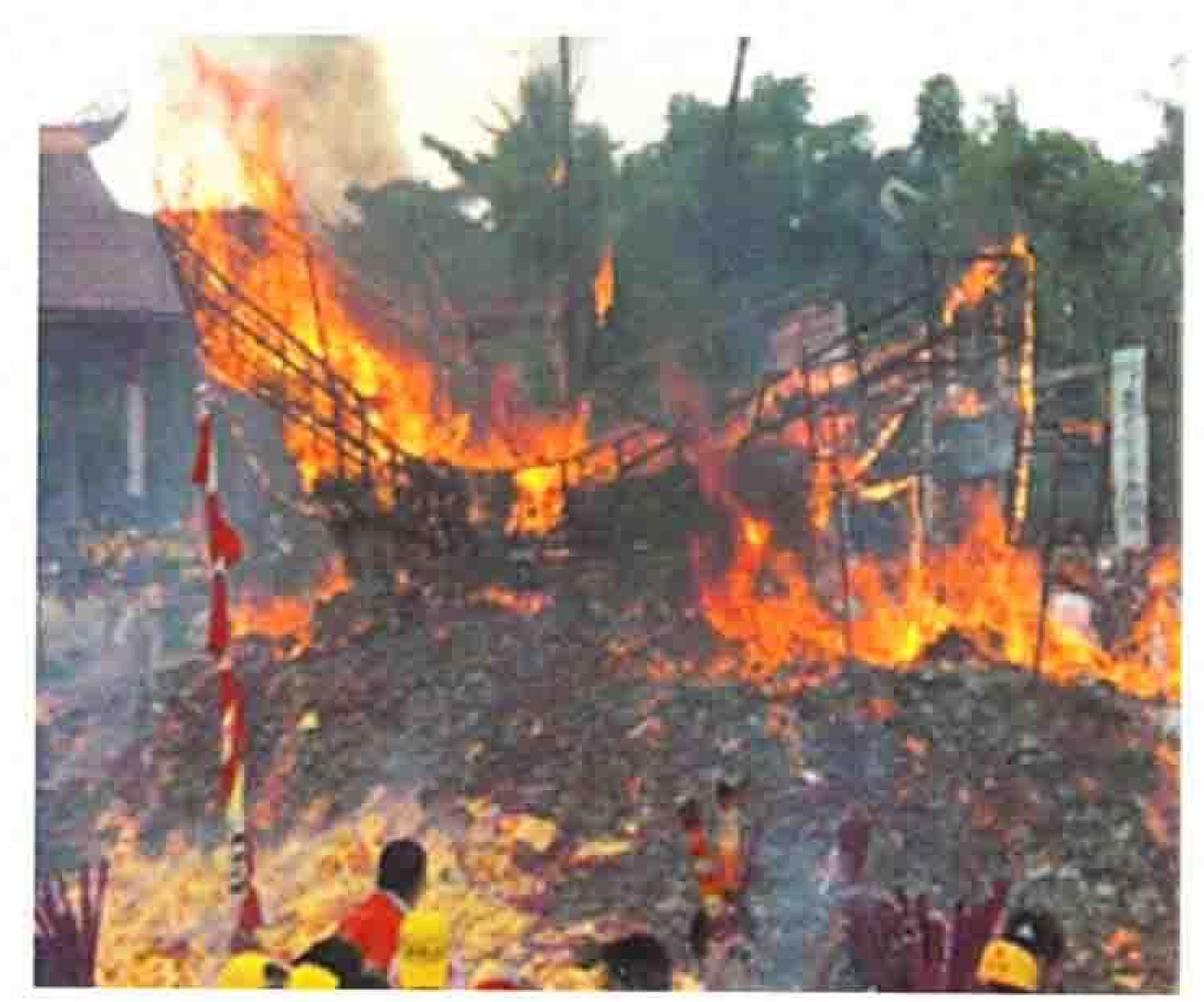


masih dihiasi lengkap oleh benderabendera berwarna-warni cerah, lukisan pada kain yang menghiasi tongkang, juga layar berwarna putih. Sebelah kanan, kondisi replika tongkang yang sudah hampir hangus seluruhnya, namun warga Tionghoa dan penonton masih menunggu ke arah mana tongkang akan jatuh. (Sumber: Riautourismboard dari http//wwiw. riautourismboard-bakar-tongkang. html).

Di sisi lain, peran serta pemerintah dalam pelaksanaan acara tersebut adalah ikut mensukseskan gema ritual diantaranya adalah pemasaran acara bakar tongkang merupakan dan ini usaha atau jalan untuk mendapatkan income baru bagi daerah melalui pariwisata.

Melalui pariwisata bakar tongkang ini, icon atau identitas budaya, sosial, dan ekonomi sudah terbentuk menggantikan identitas lama Bagansiapiapi sebagai kota industri ikan. Menggemanya otonomi daerah yang memunculkan aset-aset lokal yang harus ditonjolkan, tentu saja menjadi alasan bahwa pembentukan sebuah identitas adalah salah satu strategi untuk memperoleh pendapatan, terlebih identik dengan pencitraan sesuatu.

Ritual Bakar Tongkang memang bentuk keakuan (Abdillah, 2002) dari identitas Bagansiapiapi sebagai jargon etnisitas Tionghoa di sana yang berbeda dengan identitas budaya maupun identitas sosial-ekonomi dan keagamaan Tionghoa di kotakota lain, baik di Indonesia maupun mancanegara, bahwa Go Cap Lak hanya terdapat di kota Bagansiapiapi, kabupaten Rokan Hilir, provinsi Riau.

\section{Kesimpulan}

Perayaan atau upacara Go Cap Lak merupakan ritual tahunan yang diselenggarakan oleh masyarakat Tionghoa di Bagansiapiapi. Ritual ini diselenggarakan pada bulan kelima (Go) imlek di tanggal enam belas ( Cap Lak) sebagai ungkapan syukur dan terima kasih kepada Dewa Laut yang telah memberikan kemakmuran dan kesehatan.

Cap Go Lak merupakan upacara bakar tongkang yang hanya terdapat di Bagansiapiapi dan dijadikan sebagai icon atau identitas budaya untuk menarik wisatawan.

Dalam perkembangannya, bukan hanya identitas budaya saja, namun juga memberikan angin segar bagi perekonomian dan keragaman kehidupan sosial di kota Bagansiapiapi. Memang ritual Go Cap Lak atau bakar tongkang menjadi identitas baru bagi Bagansiapiapi dan menggeser identitas lama dari kota penghasil ikan nomor dua dunia di pertengahan abad ke-20. 


\section{DAFTAR PUSTAKA}

Abdillah, Ubed. Politik Identitas Etnis: Pergulatan Tanda Tanpa Tanya. Magelang. Indonesia Siatera. 2002.

, Dinas Pariwisata Seni Budaya Pemuda dan Olahraga. Potensi Pariwisata Kabupaten Rokan Hilir, brosur. Bagan Siapiapi. Pemerintah Kabupaten Hilir Dinas Pariwisata Seni Budaya Pemuda dan Olahraga. 2007.

Habermas, Jurgen. The Philosophical Discourse of Medernity. Diterjemahkan oleh Frederick Lawrence. Cambridge. Polity Press. 1992.

Lufti, Muchtar (ed.). Sejarah Riau. Pekanbaru. Pekanbaru. Unri Press. 1977.

Pemda Rohil. Pesona PariwisataRokanHilir.Pemerintah Kabupaten Rokan Hilir. 2007.

Piliang, Yasraf Amir. Sebuah Dunia yang Dilipat, Realitas Kebudayaan Menjelang Millenium Ketiga dan Matinya Postmodernisme. Bandung. Mizan.1999.

Poerwanto, Hari. Orang Cina Khek dari SingkawangI. Depok. Komunitas Bambu. 2005.

Setyawati, Shanti. Pasang Surut Industri Perikanan Bagansiapiapi Tahun 1989-1936. D e p o k. Universitas Indonesia (Thesis), 2009.
Sutrisna, Deni, Ery Soedewo, dan Lucas Partanda Koestoro. Situs dan Objek Arkeologi di Kabupaten Indragiri Hulu Provinsi Riau", dalam Berita Penelitian Arkeologi No.15. Medan: Balai Arkeologi Medan. 2006.

Alfan, Zainal dalam http://kabrokanhilir.bpn.go.id/Propinsi/ Riau/Kabupaten-Rokan-Hilir/ Berita, 19 Januari 2012 diakses 18 Juni 2012.

Wikipedia. Bakar TongkangBagansiapiapi. (online) http.//. www.wikipedia.org/wiki/ritual bakar_tongkang. Diakses 16 Juni 2012.

Kompas. Julukan Kota Ikan itu, Kini Tinggal Nama .31 Oktober 1995 (diakses 23 Maret 2012) 